Published in Patterns of Prejudice, Vol. 32, No.2, pp. 15 - 37

\title{
Asking Ethnic Questions: some hows, whys and wherefores
}

\author{
Roger Ballard
}

\section{Introduction}

That ethnic and racial disjunctions are, de facto, one of the most serious, and indeed one of the most explosive, sources of socio-political tension in the contemporary world is plain to see: all but the very smallest island-based societies, whether in the "developed" or the "under-developed" world, are more or less severely fissured in this way. Yet despite the salience of these disjunctions, much confusion still remains - not least amongst social scientists themselves - as to how the structure of such plural societies can best be conceptualised, and hence as to how the construction of their various component sections, as well as their mutual dialectics can best be described and understood. With this in mind it is worth remembering that it is not long since it was almost universally assumed that the very existence of divisions was the outcome of intrinsically irrational patterns of prejudice. Hence - or so it was supposed - as the world's inhabitants became ever more prosperous, and hence more intellectually sophisticated and educationally informed, disjunctions of this kind would steadily fade into a condition of ever-greater insignificance.

Although the universalistic assumptions which underpinned these expectations soon became an article of faith right across the political spectrum, from Marxists on the left to liberal free-marketeers on the right, it is nevertheless worth remembering that the Western European social and political arenas within which these ideas were initially generated also played host to some equally powerful anti-universalistic counter-currents. Amongst the most important of these was the notion the world's population was intrinsically non-homogeneous. Rather it was held to be divided into a large number of separate nations, each of which was marked off from all others by virtue of its members distinctive religious, cultural, linguistic and/or biological heritage. Hence whilst a commitment to universalism, and hence to the illegitimacy and indeed irrationality of sustaining racial and ethnic disjunctions, was a central feature of the Western European enlightenment, such notions were by no means left unchallenged. On the contrary the view that national self-expression articulated through a democratically constituted nation-state was by far the most just and effective means of articulating the popular will was just as important a product of Western European thinking during the same period, and has swept the globe with equal if not greater impact during the course of the past century.

The results of these two deeply contradictory trends are now plain to see. Whilst all the Imperial structures whether Mughal or Ottoman, Chinese or Czarist, British or Austro Hungarian which had hitherto been such a salient feature of the global order have been systematically swept away, it is not so much universalism, but rather the nation-state which has universalised itself. So it is that at an organisational level nation-states have become ubiquitous. To be sure some of the new units, such as Afghanistan and Somalia, have imploded in tatters. Nevertheless following the collapse of the Soviet Union, every formal Imperial structure has come to an end, and the United Nations has grown to include nearly 
two hundred separate members. But if the idea of universalism in the sense of an everincreasing tendency towards global homogeneity has proved to be an empty dream, a powerful commitment towards what can usefully be identified as a lesser form universalism has now sprung up, paradoxically enough, within the boundaries of almost every contemporary nation state. The reason for this is equally plain to see. At the heart of almost every nationalist program is an expectation that the people who make up the nation are - or should at least be actively committed to making themselves - ethnically and linguistically homogeneous. ${ }^{1}$

Nevertheless this dream is also proving to be equally elusive. However much its' supporters have sought to achieve a condition of comprehensive religious, linguistic and cultural homogeneity, virtually every contemporary nation-state is marked by some degree of ethnic plurality. Nor is this condition merely a temporary aberration: everywhere one looks, although for a whole host of differing reasons, that condition of plurality is becoming more and not less salient. Britain is no exception to this trend. Over and above the differences between the United Kingdom's three regional components of England, Scotland and Wales, additional dimensions of diversity have been introduced by the growth of substantial minority populations of less indigenous origin. Largely as a result of the ever-increasing demand for additional labour which accompanied the process of nineteenth and twentieth century industrial expansion, large numbers of migrant workers were drawn into mainland Britain from overseas. And whilst some of those settlers were physically indistinguishable from their more indigenous counterparts, as in the case of members of the Jewish and Irish Catholic communities, others were much more readily identifiable. This was particularly so during the course of the past half century, during which the majority of newcomers traced their ancestral roots to one part or another of Asia, Africa and the Caribbean. Hence Britain's visible minority population now includes around three million people, or some six percent of the population as a whole. ${ }^{2}$

Analysing the extent and significance of Britain's resultant condition of pluralism is, however, proving to be a major sociological challenge. Just what kind of structural positions have each of these minorities come to occupy in the wider social order? Is their behaviour becoming steadily more akin to that of the indigenous majority - as universalistic expectations suggested both would and should occur? Or are each of the new minorities sustaining a sense of their own distinctiveness? In any event just what trajectories of adaptation has each group followed since the earliest pioneers established a toehold in their new environment? Have they followed the path of comprehensive cultural assimilation which supporters of the nationalist variant of universalism insisted must take place? Or have some or all - of these groups successfully sustained a degree of ethnic autonomy? Moreover just what have been the consequence of these strategies? How far have those involved, whether theirs is a visible or an invisible minority, remained trapped in the unattractive jobs and houses to which they were initially assigned? And how far, to the contrary, have they managed to challenge the exclusionism to which they were exposed, and to push their way upwards and outwards to positions of greater prosperity? And if they have indeed succeeded in so doing, is their success an indicator of the absence of racial and ethnic exclusionism, or is it better understood as an indicator of the extent to which those involved have used the

\footnotetext{
${ }^{1}$ As Garibaldi famously put it immediately after having gained political control of Italy in 1861 , AWe=ve made Italy, now we must make Italians .

${ }^{2}$ See Ballard, R., and Kalra, V.S., The Ethnic Dimensions of the 1991 Census: A preliminary Report (Manchester: Manchester Census Group, 1994).
} 
resources of their distinctive cultural capital to devise strategies which have enabled them to overcome those constraints?

\section{Gearing up for an ethnic question: the UK Census of 1991}

Until recently lack of data made it virtually impossible to explore these questions with any degree of clarity or confidence. Nor was this situation easy to remedy, given that any attempt even to broach such issues could be perceived as intrinsically anti-universalist and therefore "racist". Hence the very proposal that a question on ethnic affiliation might be included in the Census - and by extension in all manner of other data-collection exercises - invariably encountered vociferous opposition, much of which was articulated by otherwise liberalminded sociological commentators. ${ }^{3}$ Yet however well meaning their objections may have been, the analytical consequences of their arguments were quite disastrous. In the absence of the clear-cut statistical data all discussions about the shape, size and social characteristics of Britain's minority communities - let alone of the extent to which Britain was in fact becoming a plural society - became a matter of more or less impressionistic guesswork.

Against this background the inclusion of a deliberately formulated ethnic question in the 1991 Census (although not, paradoxically enough, in the version of the Census schedule used in Ulster), and the consequent use of a similar question in all manner of other data collection exercises, was undoubtedly a major step forward. To be sure there were many deficiencies in the format of the question which was deployed, not least because it was solely concerned with identifying the visible components of Britain's minority population. That said, the exercise has nevertheless been of considerable utility, for it has generated a vast mass of data about the social, economic and demographic characteristics of the six most salient components of this section of Britain's population. Moreover despite its limitations this data has also become available at a particularly opportune moment, given that a full half a century has now passed since the process of mass migration from Britain's former Imperial possessions began.

As a result of the length and intensity of Britain's involvement in Imperial activities, its population has had a long history of more or less intimate contact with its non-European subjects. Although there has been a small non-European presence in Britain ever since the West African trade began to open up during the course of the sixteenth century, it was not until the post second world war economic boom took off - such that large sections of British industry began to run acutely short of labour - that non-European migrants began to settle in Britain in substantial numbers. Whilst this migrant inflow which was largely responsible for the growth of Britain's current visible minority presence, it is essential to emphasise (if only because the point is so often forgotten) that immigration itself was by no means a novel phenomenon. During previous episodes of rapid industrial expansion migrant workers had been drawn in from rather nearer at hand, and most especially from Ireland and Eastern Europe. But by the early nineteen fifties these traditional reservoirs were well nigh exhausted, with the result that additional hands began to be drawn in from much further afield. But this new window of opportunity - at least from the migrants' point of view - did not remain open for long. Although the demand for labour stayed high, from the mid nineteen sixties onwards

\footnotetext{
${ }^{3}$ The presentations made by Robert Moore and Attam Vetta to a Select Committee of the House of Commons (Home Affairs Committee, Ethnic and Racial Questions in the Census, HC 33-1, 1983) are a particularly clear example of such arguments.
} 
ever more draconian restrictions began to be imposed on the entrance of migrant workers from South Asia and the Caribbean, in an effort to assuage growing popular hostility to their presence. Yet despite the vigour of popular demands to "halt immigration", the authorities soon discovered that the inflow was far from easy to turn off, largely because it was hard to prevent those who had already arrived (most of whom were men) from exercising their rights of family reunion. Hence the inflow continued to increase for some while - although the pattern varied as between different groups - before it finally fell away. Hence most visible minorities' peak period of settlement occurred at least a quarter of a century ago.

Like all other migrant workers, South Asian and Afro-Caribbean settlers soon found that on arrival they had little alternative but to start right at the bottom of the pile, and thus to take the jobs and to live in the houses which more established members of the local population some of whom were immigrants from an earlier era were only too willing to abandon in favour of better opportunities elsewhere. Yet despite this initial condition of structural disadvantage, which was, of course, very similar to that which their Jewish and Irish Catholic predecessors had also experienced, they were no less committed to overcoming those difficulties in the longer run. But all migrants soon realise, upward mobility in an alien and often hostile environment can rarely, if ever, be reaped overnight. More often than not it was their locally-born children, rather than members of the migrant generation themselves, who were most likely to reap the full benefits of their enterprise.

Once set in this context, the full significance of the inclusion of an ethnic question in the 1991 Census springs into focus. Half a century has now passed since mass migration began, and in most communities at least a quarter of a century since the inflow reached its peak. Hence we are now in an excellent position to begin to assess how each of these communities has fared during the intervening years, and thus how far their hopes of upward mobility have in fact materialised; secondly, and perhaps most significantly, we can now begin to explore just how varied these trajectories of adaptation have proved to be.

\section{Racial disadvantage and ethnic resourcefulness}

Whilst the inclusion of an ethnic question in 1991 Census as well as in the $4^{\text {th }}$ National Survey of Ethnic Minorities conducted by the Policy Studies Institute (PSI), ${ }^{4}$ has at long last provided us with the statistical wherewithal with which to address such questions, making sense of the results is turning out to raise some far more complex issues than most sociological commentators appear to have expected.

To date the great majority of sociologists have taken the view that in analytical terms the most important distinguishing feature of the new minorities was their physical visibility, or to put it more precisely, the routine tendency of members of Britains indigenous majority to use physical appearance as a marker of alterity; and to the extent that this is so everyone who can be identified as "not-white" is subjected to a more or less intense degree of racial exclusionism, thus placing them in a measurable position of racial disadvantage. That there is considerable force in this perspective is now beyond doubt: as members of this section of the population routinely report, in almost every conceivable circumstance their physical distinctiveness $i$ s taken into account by members of the "white" majority; and the consequent tendency towards racial marginalisation is particularly strong whenever they find themselves

\footnotetext{
${ }^{4}$ T. Modood, R. Berthoud, J. Lakey, J. Nazroo, P. Smith, S Virdee and S. Beishon, Ethnic Minorities in Britain: Diversity and Disadvantage (London: Policy Studies Institute 1997)
} 
in direct competition with members of the indigenous majority for access to the same set of scarce resources.

Yet however severe the negative consequences of their inherited physical distinctiveness may be (for the implications of having an expensively acquired sun-tan are of course quite different), it is surely quite wrong to conclude - as all too many sociologists seem prepared to assume - that the social fate of everyone subjected to such denigratory treatment will be entirely determined by that experience, or indeed that "Black" people in this sense will form anything like the homogeneous population category that such racist usage inevitably suggests. Quite the contrary. Whilst the almost obsessional concern with hereditary differences in physical appearance which most white Britons display may indeed generate a common experience of exclusion amongst members of the visible minorities, from their own perspective those so identified may well share little or nothing else in common. Hence however angered they may all feel about their white compatriots' bizarre attitudes, it most certainly does not follow that every single aspect of the lives of members of Britain's "notwhite" population is primarily determined that experience. Nor are their responses to those constraints uniform either. Although members of every section of the visible minority population have now begun to devise strategies with which to contest and resist their exclusion, these are proving to be neither homogeneous nor uniform.

Nor is it hard so see why minority reactions to their experience of exclusionism have been far more varied than the myopic assumptions of the sociological establishment has hitherto been prepared to acknowledge. However homogeneous that category of people who have been successively identified as "coloured", as "immigrants" and now as "Black" may have seemed to "White" observers, what all of these labels have served to obscure is the extent to which those so identified were in fact affiliated to a multitude of differing communities, each with its own very specific roots; and that however much white observers may have dismissed the significance of these affiliations, it is through the prism of their own specific social, cultural, linguistic, familial and religious heritage that every group of settlers has set about constructing networks of mutual support - communities, in other words - the better to survive and resist the unwelcome forces of racial exclusionism to which they were all to frequently subjected. Hence rather than seeking to bring their personal lifestyles into comprehensive conformity with indigenous norms as fast as they possibly could as most "white" observers naively expected they would and should most members of the visible minorities have followed precisely the opposite course. By looking to each other for mutual support they have generated ever more elaborate ethnic aggregations of their own. Nor were these developments in any way unprecedented. To the extent that the new minorities have settled together in residential clusters within which they have made elaborate efforts to rebuild their personal and domestic lives on their own terms, they are following strategies which are very closely akin to those deployed by their less immediately visible Jewish and Irish predecessors.

The broad outcome of these processes is now plain to see. On the one hand Britain become a society which is significantly multi-racial, so much so that between a quarter and a third of the newly born children in many of its major industrial cities are now born to parents of non-European ancestry; and on the other its social order has become much more overtly plural in the sense that its inhabitants now display a wider variety of personal and domestic lifestyles than ever before.

Yet just what are the implications of these developments, and how is their wider significance - not least from the perspective of social policy - best understood? Although many members of Britain's indigenous majority undoubtedly regard the increasing salience 
of ethnic plurality with considerable alarm, largely on the grounds that it represents an unacceptable challenge to the integrity of the established social order, and despite the equally widespread tendency to use these perceptions as a further justification for exclusionistic practices, it is now becoming increasingly clear that the new minorities have by no means been overwhelmed by all this. Not only have they managed to stand their ground and defend their own interests, but very often to prosper despite all these difficulties. And this, in turn, prompts yet more questions: just how far, and how comprehensively, have the new minorities managed to overcome the obstacles they have encountered, and if so when, where, and on what basis?

\section{The findings of the 1991 Census}

With this in mind one of the most significant outcomes of the 1991 Census - which have been further underlined by the results of PSI's Fourth National Survey - is that although the visible minorities may indeed have been pressed into the position of a comprehensively deprived underclass when they first arrived in Britain, and although they were hit with disproportionate severity by the impact of the industrial recession of the early 1980s, the grossest forms of social inequality as between the "White" majority and the "non-white" minorities have by now been almost entirely eliminated. Indeed as the figures in Table 1 demonstrate, by the time the Census was conducted in 1991 there was - remarkably enough very little difference in the aggregate distribution by social class of the visible minorities as opposed to the white majority, no less so amongst women than amongst men. Nor is that all. At the younger end of the age spectrum (which is, of course, the sphere which provides the best indication of the likely direction of future trends) members of the minorities have now begun to outperform the indigenous majority.

Table 1: Percentage distribution by Social Class of White and Non-White men and women by age-group

\begin{tabular}{|c|c|c|c|c|c|c|c|c|}
\hline \multirow[b]{2}{*}{ Men } & \multicolumn{2}{|c|}{ Aged $18-29$} & \multicolumn{2}{|c|}{ Aged $30-44$} & \multicolumn{2}{|c|}{ Aged 45-59 } & \multicolumn{2}{|c|}{ Aged $60+$} \\
\hline & White & Non-White & White & Non-White & White & Non-White & White & Non-White \\
\hline Professionals & 5.8 & 7.3 & 8.2 & 10.4 & 7.3 & 9.3 & 6.6 & 6.6 \\
\hline Managers & 20.4 & 22.2 & 33.3 & 28.4 & 32.3 & 22.3 & 26.4 & 15.1 \\
\hline Non-manual & 14.8 & 20.5 & 9.5 & 10.4 & 8.5 & 9.3 & 9.7 & 9.5 \\
\hline Skilled manиal & 32.7 & 24.8 & 31.3 & 28.1 & 32.3 & 28.5 & 31.4 & 28.3 \\
\hline Semi-skilled & 17.1 & 16.5 & 1.9 & 15.9 & 14 & 21.2 & 18.5 & 25.1 \\
\hline $\begin{array}{l}\text { Unskilled } \\
\text { Women }\end{array}$ & 5.5 & 4 & 3.4 & 3.4 & 4.2 & 6.8 & 6.2 & 12.5 \\
\hline Professionals & 2.4 & 3.6 & 2.2 & 3.1 & 1 & 1.9 & 1 & 1.1 \\
\hline Managers & 25.1 & 21.9 & 32.2 & 31.3 & 27.5 & 33.4 & 22.2 & 30.4 \\
\hline Non-manual & 45.1 & 49.6 & 36.2 & 29.9 & 35.4 & 14.1 & 34.1 & 10.1 \\
\hline Skilled manual & 7.7 & 5.2 & 6.1 & 6.2 & 7.3 & 7.4 & 6.8 & 7.8 \\
\hline Semi-skilled & 15.2 & 14.5 & 15.8 & 22.9 & 16.9 & 28.8 & 17.6 & 25.8 \\
\hline Unskilled & 3 & 2.4 & 6.8 & 4.4 & 11.1 & 12.2 & 17.2 & 22.2 \\
\hline
\end{tabular}

Source: 1991 Census Ethnic Group and Country of Birth Topic Report, Table 10 
But if these figures provide the clearest possible evidence of just how inappropriate it now is to categorically identify Britains visible minority as an underclass, this generalisation nevertheless conceals at least as much as it reveals, for one of the great merits of the ethnic question is that it enables us to cut our way through the stereotypical focus on skin colour which is so characteristic of "White" discourse, and to explore the differential experiences of the major internal components of the visible minority population. In these terms another striking feature of the Census results - also confirmed by the findings of the PSI's Fourth National Survey - is the very high level of differentiation which has now begun to emerge as between different subsections of the visible minority population. . These are so great that in virtually every sphere of activity which we are now in a position to explore, inter-minority differences are invariably substantially greater than those between the "Whites" and "nonwhites" as a whole. In other words "non-whites" differ more from each other than they do from "Whites".

Finding a way of comprehensibly representing the character of these differentials, let alone of suggesting just how they may have arisen, has turned out to be an even more challenging task than I initially envisaged. Nevertheless I hope that the preliminary attempts that I have made to do so will prove to be reasonably illuminating. With this in mind the figures set out in Tables 2 to 5 disaggregate in ever increasing detail the association between ethnic affiliation and socio-economic status, with the object of showing just how substantial (and how varied) the scale and complexity of these patterns of variation have now become. Looking first of all at Table 2, which explores the relationship between age and socioeconomic status amongst non-White men, the data are displayed in three columns. The first shows the number of men of that age-group found in each socio-economic group, (based on a $10 \%$ sample of the UK population), the second the percentage of men in that age group who are members of that category, whilst the third shows the ratio between that figure and the percentage of White men in that self-same category. Hence a figure of 1.0 in the ratio column indicates that those figures are identical, a figure of 2.0 that minority men are twice as frequently found in that category, and 0.5 that their presence there is only half as great. Table 3 has a similar format, but shows the figures for women rather than men.

\section{<Tables 2 and 3 about here>}

There are, of course, some problems with these figures, most especially when numbers in the underlying cell size are small: amongst, for example, large employers, or farmers and agricultural workers, of whom there relatively few in the population at large, or amongst older Pakistani and Bangladeshi women, of whom only a tiny and very unrepresentative proportion are economically active. These reservations apart, the underlying counts in most parts of these Tables are sufficiently large for calculated results to be of reasonable statistical significance, and yet further confirm the broad pattern of upward mobility indicated by the aggregate figures in Table 1. Thus whilst non-white men of all age groups may still be significantly over-represented (ratio>2.0) amongst personal service workers, they are also similarly over-represented amongst small employers; meanwhile the only areas in which they are substantially under-represented (ratio<0.5) is in agriculture, and amongst the older age groups as managers in large establishments. Meanwhile young nonwhite women are now gradually beginning to make a significant showing - at least in relative terms - as small employers and self-employed professionals, even if older women are still strongly over-represented in semi-skilled manual work. 
Yet if Tables 2 and 3 provide further indications of the extent to which the visible minorities have begun to move upwards through the socio-economic pile, Tables 4 and 5 , which further disaggregates the ratio calculations set out in the previous pair of Tables by ethnic group, demonstrates that this pattern of upward mobility is by no means uniform, either in its extent, its direction, or in its gendering, across the various minority groups we are now in a position to identify. Taking the percentage distribution of the majority population by socio-economic group as our yardstick once again, Indian, Pakistani, Bangladeshi and Chinese men of all ages turn out to be particularly strongly over-represented amongst small employers, whilst Bangladeshi and Chinese men are hugely over-represented in the "personal service workers". Evidence from elsewhere in the Census - which it would be tedious to present in detail here - suggests that this is a result of their heavy (but nevertheless differential) concentration in the restaurants, take-aways and taxi-driving. What is also striking about Table 4, however, is the striking degree of upward mobility into professional activities - on both an employed and self-employed basis - which has by now been achieved by the Chinese and the Indians, and to a rather lesser extent by the Pakistanis and the Africans. Meanwhile Table 5 shows that some equally complex, but rather differently patterned, differentials have also begun to emerge amongst visible minority women. To be sure their current levels of achievement are on the face of it rather less great than those of their male counterparts: this is only to be expected given that in their case the forces of racial exclusionism will be further supplemented by those of gender. Yet if older minority women are still heavily concentrated (and hence over-represented) in various forms of manual work, this tendency is a good deal less salient at the other end of the age spectrum. Moreover in some groups, and most notably so amongst the Afro-Caribbeans, younger women have now begun significantly to outperform their male counterparts (although not white women) in gaining access to managerial, professional and semi-professional jobs. Beyond this Table 5 also suggests that some even more substantial changes may well be in the pipeline, since in all six minority groups women aged between 18 and 29 display a very substantial (although inter-ethnically variable) degree of upward mobility in comparison with their counterparts in the two older cohorts. ${ }^{5}$

\section{The interaction between racial inequality and ethnic diversity}

How can we best make sense of these exceedingly complex outcomes, which are replicated in almost every area of social activity which we are now in a position to explore? And however

\footnotetext{
${ }^{5}$ It is also worth commenting on the extraordinarily levels of success with which older Pakistani and Bangladeshi women, and to a slightly lesser extent their Indian counterparts, appear to have gained entry into professional self-employment. Whilst the data itself is accurate enough in its own terms, it must be remembered that the this section of the Census only counts persons who are "economically active", or in other words engaged in formal paid employment of one kind or another; and although a large proportion of older Pakistani and Bangladeshi women are ill-paid homeworkers, (for many are most reluctant to take employment in nondomestic contexts) they are officially classified as "economically inactive". But although the proportion of older Pakistani and Bangladeshi women who are economically active according to these criteria is very low, those that are in paid employment are for the most part drawn from a small professional elite of Doctors. The figures in most other parts of table 5 can only be properly understood in the light of a similar intimate knowledge of the sociological character of the underlying community.
} 
imperfectly focussed the statistical pictures which we are currently able to generate may be, how can we best begin to approach the task of exploring the character of, together with the interaction between, all the social, economic, historical and cultural processes which have given rise to these outcomes? Moreover if this task poses all sorts of analytical challenges, it is also worth reminding ourselves that when the current ethnic question was actually framed, few of those who were actually responsible for the whole exercise seem to have envisaged that the results would be anything like so complex, or indeed so difficult to interpret, as they have actually turned out to be.

As I argued in an earlier contribution to Patterns of Prejudice, ${ }^{6}$ virtually everyone who participated in the debate about the pros and cons of including an ethnic question in the Census not only appear to have taken it for granted that the central object of the exercise was to identify the "not-White" component of Britain's population, but also that by far the most important analytical filter through which the results of the initiative would be processed was that of "racial disadvantage". Hence as the House of Commons Select Committee Report which formally set the ball rolling quite explicitly put it: 'The object of asking ethnic questions is, in conjunction with other indicators of general disadvantage, to assist Government and local authorities to identify and work against all aspects of racial disadvantage and racial discrimination. ${ }^{77}$ If members of the sociologically inexpert Select committee could perhaps be forgiven for following vernacular usage by assuming that the concepts of 'race' and 'ethnicity' could legitimately be regarded as virtually synonymous analytical categories, and for going on from that position to wrap up the whole exercise within the further assumption that discrimination and disadvantage were principal issues which the results of asking the new question would serve to highlight, what is very striking is that in the aftermath of the whole exercise the vast majority of academic commentators appear to have been content to operate within a similarly structured analytical universe.

Although this tendency can certainly be identified in many of the commentaries on the results of the 1991 Census, ${ }^{8}$ it is particularly - and very illuminatingly - manifest in the fourth (and broadly sociological) volume on Ethnicity in the 1991 Census which has recently been published by the Office for National Statistics. ${ }^{9}$ Almost every Chapter in the volume points to the presence of very considerable inter-minority variation, so much so that in her concluding overview the editor, Valerie Karn, goes out of her way to emphasise her agreement with Blackburn, Dale and Jarmans conclusion that

Conventional perceptions of immigrants forming an 'underclass' or otherwise sharing a common experience of deprivation are unsound. This is not to deny that ethnic minorities, or at least those not classified as White, suffer disadvantages; the evidence on lifestyles and unemployment show this. However, their experiences are not homogeneous and they are not passive victims. ${ }^{10}$

\footnotetext{
6 "Negotiating Race and ethnicity: exploring the implications of the 1991 Census" in Patterns of Prejudice, Vol. 30 No. 3, pp 3 - 33.

${ }^{7}$ Home Affairs Committee, Ethnic and Racial Questions in the Census, HC 33-1, 1983, p. ix

${ }^{8}$ See, for example, my review article “The construction of a Conceptual Vision: 'Ethnic Groups' and the 1991 UK Census" in Racial and Ethnic Studies, Vo.20, pp. 182 - 194.

${ }^{9}$ Karn, Valerie (ed.) Ethnicity and the census Volume 4: Employment, Education and Housing amongst the ethnic minority populations of Great Britain (London: Office for National Statistics, 1997).

${ }^{10}$ Karn (ed.), 282). The contributors to the PSI's Fourth National Survey reach a similar conclusion when they suggest that 'Pakistanis and Bangladeshis are consistently at a disadvantage with respect to white people, and often with respect to other minorities .... People of Caribbean and Indian origin are often found to experience disadvantage, though it is usually less serious ..... Chinese people and East African Asians have reached a
} 
Even so neither she, nor any of the other contributors to the volume, make any serious attempt to break out of the procrustean limitations of what I have described elsewhere as the "deprivationist paradigm". "So it is that even though Karn immediately goes on to cite Malcolm Cross's comment to that "to speak of "the Black experience" to signify all the richness of the Diaspora is both to simplify the everyday processes of exclusion and to minimise the creativity of response' with approval, ${ }^{12}$ she makes no effort whatsoever to explore the possible impact of ethnic creativity. On the contrary she returns immediately to the language of deprivationism by suggesting that "there is one respect in which one can speak of a general "Black experience", namely that all minority groups suffer a "penalty", albeit of varying size, relative to the White population.'Hence the central objective of Karn's Chapter, and in a more general sense of the whole volume, is to assess the extent to which the visible minorities suffer from such an 'ethnic penalty', and to outline the steps which she believes should be taken largely through reinfor cing the powers of the Commission for Racial Equality to reduce or better still to eliminate the impact of this penalty.

Yet although the worthiness of Karns concern to identify the nature and extent of this penalty is beyond question, just how adequate, and above all how analytically illuminating is the conceptual perspective within the context of which she - along with a whole host of other sociological commentators - has chosen to articulate her arguments? In raising this query I should perhaps begin by emphasising just where any differences between us might lie, not least because I wholly agree with the proposition that all members of the visible minorities do indeed experience something which can quite legitimately be described as a 'penalty' as a result of the impact of white exclusionism. Hence it is not so much over whether or not the visible minorities find themselves penalised as result of the attitudes and behaviour of the White majority that that I would wish to differ from Karn (as well as from the many other sociological analysts who operate within the context of a similar analytical perspective), but rather with respect to the vocabulary which she - and they - have chosen to deploy in order to investigate the phenomenon. Is the penalty ethnic? Or is it more appropriate to identify it as racial?

At first sight this might well seem to be no more than an arcane terminological quibble, since in vernacular speech (just as in the Census itself) the terms 'ethnic' and 'racial' are routinely employed as virtual synonyms. Yet although words can mean, as the Red Queen insisted, "just what I choose them to mean, and neither more nor less", this commonplace usage is having a quite disastrous impact - or so I would argue - on our ability to comprehend the changes and developments which are currently taking place in our increasingly plural society. The central consequences of eliding these two terms - the first of which has only very recently come into widespread usage - are not difficult to identify. Firstly the term ethnicity now serves as a very convenient euphemism for the morally discredited concept of race. Yet precisely because it is deployed in this way, it follows that it may well enable its users to make exactly the same kind of social distinctions as were made in the past, but to do so on what can now be represented as a much more morally acceptable basis. Secondly this elision strongly confirms the popular view that it is the minorities who "are different", as opposed to the merely normal majority, who consequently see themselves

position of broad parity with the white population - behind on some indicators, perhaps, but ahead on others. It would be inappropriate to describe them as disadvantaged groups.' (Modood et.al.)

11 Ballard, Roger, "New Clothes for the Emperor? The Conceptual Nakedness of the British Race Relations Industry" in New Community Vol. 18, 1992

${ }^{12}$ Ibid. 
as 'not-ethnic' - just as the vocabulary of the Census quite explicitly confirms. This has a further set of consequences, for if Whites are by definition 'not-ethnic', it follows that any possibility that this section of the population might have any kind of ethnic specificity, or more seriously still, that it might be ethnically heterogeneous, is simply ruled out of court in conceptual terms. The invisible minorities within its own ranks are, as it were "disappeared". Lastly, and perhaps most of importantly of all, this usage firmly reinforces the position of ethnic privilege enjoyed by Britain's established - and of course overwhelmingly English elite. Not only does it serve to suggest that the established social order really is as homogeneous and as unresisted as those who stand at its heart would like everyone else to believe, but also enables them to identify as 'normal' - and so put beyond the reach of analytical scrutiny - their own very specific interests, concerns and characteristic modes of expression: the very stuff of hegemony.

In so far as it is an analytical discipline, the very purpose of social science is of course to disentangle and to lay bare the operation of such processes: and it also follows that a failure to do so is of necessity to conspire - whether consciously or unconsciously - in the maintenance of the hegemonic structures which such processes serve both to organise and legitimate. Terminology does matter, and all the more so $f$ there is a prospect of it operating as a Trojan horse which introduces a hegemonic perspective into the very heart of the analytical categories routinely deployed by social scientists. Unless this danger is actively guarded against, there is a very real prospect that the whole critical purpose of our analytical procedures will be undermined.

But if this is so, just how should we differentiate between the concepts of "race" and "ethnicity" in empirical terms? Always remembering the Red Queen's ruling, there are nevertheless a whole series of crucial analytical issues which are worth disentangling here, all of which have to do with processes of boundary drawing. Boundary drawing occurs in all manner of situations, of course, but the basic logic of these processes is comparatively easy to spell out. Those involved need to begin by making a conceptual distinction between "them" and "us", but once this is in place, the way is immediately open for the "us-es" - whoever they may be, and however they may have defined themselves - to begin to act in both an exclusive and an inclusive way, making every effort to distance themselves from "them" whilst simultaneously drawing together in solidarity with all other members of "us"; and of course the "them-s" - or more likely various sub-groups of the diverse population which the original "us-es" chose to classify as "them" - are very likely to reverse the process, and to play exactly the same game themselves.

Although all manner of social groups - from the most powerful to the most resourceless - undoubtedly have the capacity to mobilise in this way, the structural consequences of their activities differ. As Parkin has very usefully pointed out, ${ }^{13}$ the resulting processes of closure can conveniently be identified either as exclusionary (as when members of privileged groups who have much to lose and hence regard competitors of all sorts as most unwelcome), usurpationary (the strategy typically deployed by disprivileged groups who have little to lose and much to gain by challenging others), and dual (most frequently deployed by those in the middle, and whose objective is therefore both to exclude potential competitors from below whilst also challenging those who stand above them). Last but not least, the criteria deployed to organise and defend these boundaries, whether for the purposes of exclusionary or usurpationary closure, or - most commonly - in simultaneous pursuit of both these objectives, is specific to those involved in constructing them.

\footnotetext{
${ }^{13}$ Parkin, Frank Marxism and class theory: a bourgeois critique (London: Tavistock 1979)
} 
Thus even though it is quite clear that most members of Britain's indigenous majority use hereditary skin colouration, together with the "objectionable" tendency of such people to sustain their own distinctive cultural traditions, as inescapable markers of "otherness", such that those so identified find themselves subjected to various forms of racial penalty, it certainly does not follow that those so penalised will necessarily identify themselves on the same basis as their excluders do, and still less that they will begin to mobilise themselves in order to challenge the handicaps that they consequently encounter within the same ideological framework as that deployed by their excluders. On the contrary one of the most salient features of every plural society, no matter how great and well-institutionalised its internal structures of social inequality may be, is that hegemonised minorities invariably make great efforts to sustain, and where necessary actively to create, an ideological framework which differs from that promulgated by the elite, the better to resist their exclusion. Nor is that all. The usurpationary strategies deployed by the excluded tend to be particularly effective when those involved have ready access - as is normally the case amongst those of migrant origins - to a moral, linguistic and conceptual order whose premises differ radically from those which underpin the hegemonic norm. ${ }^{14}$

From this perspective a further reason why it is only Britain's visible minorities whose members are routinely perceived as 'ethnic' begins to come into focus, for it is precisely because they originate from far overseas - and not merely from the other side of the English channel or the Irish sea - that the resources on which they have drawn in devising their usurpationary strategies have indeed been radically unfamiliar, at least in terms of indigenous practices expectations. Hence there is, on the face of it, a certain logic in identifying everyone whose behaviour might be inspired by one or other of these alternative sets of social, cultural, familial, linguistic and religious resources as 'ethnic', and everyone else as not. If so, it might seem equally reasonable to suggest, pace Karn's vocabulary, that since the disadvantages encountered by non-European settlers and their offspring are precipitated by the exclusionary tactics routinely deployed by members of Britain's indigenous majority, they could quite appropriately be described as an "ethnic penalty".

Yet however harmless this terminology may seem, its inclusion in our analytical vocabulary cannot bear critical scrutiny. In the first place it is a misnomer: if members of Britain's visible minorities find themselves penalised as a result of their exposure to exclusionism, it is not so much their own (and in their terms wholly positive) ethnic commitments which give rise to these penalties, but rather the negative judgements which are made about them - and which are in turn largely precipitated by stereotyped reactions to their distinctive physical appearance - which are the principal precipitants of exclusionary behaviour. Hence it is not Karn's notion of a penalty which is in dispute, but whether the term 'ethnic' is the most appropriate means of identifying it. My own view is straightforward. If this penalty is the result of white exclusionism, we should stop beating about the bush: it is a racial penalty, and should be identified as such. But the argument does not stop there, however. Whilst the indigenous majority's almost obsessional concern with social significance of some often quite small - but hereditarily acquired - differences in physical appearance may indeed be the principal precipitant of this penalty, and so - by the same token - 'race' in this sense must also be seen as the principal vehicle through which members of Britain's self-identified White population currently practices exclusionary closure the better to defend its members' position of relative privilege, it would be quite wrong to

\footnotetext{
${ }^{14}$ It is against this background that the significance of Steve Biko's comment that "The most potent weapon in the hands of the oppressor is the mind of the oppressed" (I Write What I Like, London: Heinemann Educational, 1978: 68) immediately springs to the fore.
} 
conclude those who so identify themselves as 'White' entirely lack any kind of ethnic characteristics, or that they actually constitute anything like such a homogeneous body of people as their preferred vocabulary appears to suggest.

In the first place it is worth remembering that even though the minority group on which exclusionistic sentiments currently focus are of non-European descent, anti-immigrant exclusionism is no sense a novel phenomenon in Britain. On the contrary a whole series of less earlier groups of settlers, from the Huguenots to the Jews and then the Irish Catholics were - in their time - exposed to very similarly structured forms of exclusionism. In the second place once current disjunctions are placed within a broader time-frame, it soon becomes quite clear that Britain's English (and I stress that identifier) majority are currently suffering from one of their recurrent bouts of paranoia about the extent to which the growth of ethnic pluralism presents an unacceptable threat to national integrity. Hence, for example, Mr. Norman (and now Lord) Tebbitt's famed proposal that a 'cricket test' should be instituted to measure the extent of the new minorities' loyalty to what he and his many supporters suggest is the very essence of the British/English nation. Members of Britain's Jewish and Catholic population with any kind of historical memory will, of course, have heard this kind of argument before, and from this perspective it may well be that we are currently moving towards a much more historically precedented position, where structures of anti-immigrant and anti-minority exclusionism are articulated in much more explicitly ethnic terms.

However there is a further dimension of Lord Tebbitt's cricket test (and other similar measures) which should not be overlooked: namely the extent to which it is grounded in a very English vision of how Britain's national identity is and should be constructed. Neither Scotland nor Wales have cricket teams at all, and it is clearly grossly presumptuous to assume that the inhabitants of these regions - or indeed people of Scots and Welsh descent who are now resident in England - will, of necessity, be interested in cricket, or that they will be unquestioning supporters of the English team, and all the more so when the English so regularly, and so unthinkingly, treat the notions of British and English as synonymous. What this exposes is yet another similarly structured hegemonic relationship. As the Scots and the Welsh are very well aware, members of Britain's English majority are for the most part exceedingly reluctant to acknowledge the existence, the legitimacy and indeed the significance of the distinctive ethno-national interests of the United Kingdom's longsuppressed regional minorities. We have come the full circle. The very taken-for-grantedness of current usage, which treats Whiteness/Englishness/Britishness as virtually synonymous, has very large social consequences. Not only does it obscure the intrinsic plurality of the United Kingdom itself - of whose population the English are but one, albeit profoundly hegemonic, ethno-national component. It also has the effect of suppressing any conceptual awareness of Britain's various regional minorities, such as the Welsh and the Scots, as well as others of less indigenous origins, such as the Jews, the Irish Catholics and the TravellerGypsies, as forming intrinsic components of Britain's national whole. Moreover this also has the further effect of divide and rule. Since none of these "invisible" minorities are "ethnic" in the racial sense of the term, the non-European minorities are left looking uniquely distinctive; and despite the many parallels between the ways the two different categories of minority have in fact resisted exclusion, the invisible minorities" "deviance" remains firmly backstage. Hence the possibility that more recently arrived minority groups might legitimately sustain, an alternative moral, cultural, linguistic and religious agenda is ruled firmly out of court on the grounds that they should emulate the assimilationist strategies of their predecessors, even 
if their predecessors actually did nothing of the sort, and once encountered much the same kind of hostility as the new minorities do today. English hegemony rules!

All this has set the scene for yet more conceptual disasters, and nowhere have they been more so than with respect to White/English/British perceptions of the social experiences - and even more the intellectual, cultural and political capabilities - of non-European "others". It is, of course, in the nature of hegemony that it denies that possibility that marginalised others will ever have the capacity to set rational agendas of their own, let alone to pursue them with any degree of success: as Steve Biko was well aware, it is on this basis that both exclusion and inequality are simultaneously justified, and its effects can even come to pollute its victims' minds. But what is most striking about the vast majority of established critiques of racial inequality - or of "anti-racism", in contemporary parlance - is just how much of the established agenda of English hegemony it implicitly accepts. Hence while sociological critics (of whom Valerie Karn is only the most immediate example to hand) quite rightly seek to emphasise just how much rank injustice is precipitated as a result of racial exclusionism, close inspection soon reveals that she and most of her colleagues still fall into exactly the same hegemonic trap by failing to take the otherness of others seriously. And as long as their analytical models remain trapped within a conceptual paradigm which denies the creative possibilities of alterity, it becomes virtually impossible to concede that despite the crushing impact of exclusionism, the excluded will always find some means of resisting, or at least subverting, the preferred agendas of their excluders.

Contentious though this assertion may seem to some, I would nevertheless suggest that the results of the 1991 Census provide the clearest possible empirical evidence that this is indeed the case. Just as one might expect - at least within the context of the kind of analytical perspective which I have sought to develop here, the visible minorities ability to access some particularly rich stores of ethnic and cultural alterity has not only enabled them to move well beyond the situation of comprehensive disadvantage to which unresisted exposure to majority exclusionism would otherwise have consigned them, but has also precipitated increasingly varied trajectories of adaptation, and hence of upward mobility. That is precisely what the Census data is telling us. To be sure the task of working out just how these increasingly varied outcomes have been precipitated by the interaction between a whole series of largely ethnically inspired processes of exclusion and usurpation remains exceedingly challenging, but what seems to be plain as a pikestaff is that Karn's unidimensional concept of an "ethnic penalty" is a grossly inadequate tool for the job in hand. Worse still it seems to me that even though she may have the best of intentions she - and the many others who also follow this broad line of analysis - has thrown the baby right out with the bathwater. That is not a good remedy for anyone's health.

\section{Asking ethnic questions: the prospect for the future}

Just where do we go from here? The inclusion of an ethnic question in the 1991 Census however flawed its formulation may have been - was undoubtedly a major step forward. It has at long last begun to put a critically important dimension of diversity onto the sociological and social policy map of Britain. At the same time the very complexity of the data which it has thrown up, even with respect to the very limited range of arenas which the question posed enables us to illuminate, together with the fact that it has emphatically not fulfilled the objectives of its original advocates - namely to produce a relatively straightforward measure of racial disadvantage - makes it quite clear that we have so far only 
been able to broach the issues, and that we are still no-where near fully comprehending them. What is needed to achieve that goal?

A number of steps all seem equally crucial:

- A recognition that because we in Britain live (and have long lived) in a plural society, and that ethnic affiliation of one form or another is a feature of all sections of the population, and not just of the visible minorities.

- That the presence of ethnic pluralism is consequently a long-standing and hence in all probability a permanent feature of the British social order

- That data about ethnic affiliation is worth collecting not just as a means of assessing the extent of material inequality between our plural society's various ethnic components, but also of taking cognizance of the varying priorities which members of each such group may be setting for themselves in organizing their personal and domestic lives

- That a failure to do so yet further entrenches the hegemonic position of Britain's dominant English majority.

- That in a plural society all socio-economic outcomes will, by definition, be the product of a complex series of interactions between in-groupers' own self-defined strategic priorities and of the external constraints to which they find themselves exposed, always remembering that one group's exclusionary priorities may well be the principal source of another's external constraints.

- That any such an exercise is unlikely to be analytically productive as it should be until we establish a set of publicly accepted ethnic categories which quite explicitly include whilst also differentiating between - all the many components of Britain's population who are at present invited to identify themselves "White".

- That the whole purpose of such an exercise is not so much to explore issues of either "identity" or "origin" - given the exceedingly fickle conceptual foundations of both these terms - but rather to identify which of the many communities of which our manifestly plural society is now composed respondents feel themselves to be most closely affiliated

- And to the extent that ethnic affiliation is determined from within, British-South Asian demands that the existence of further sub-divisions within their ranks - as, for example, between Hindus, Sikhs and Muslims, as well between Gujaratis, Sylhetis, Punjabis and Azad Kashmiris - should be met with a positive response, not least because a more closely focused exploration of ethnic affiliation in the belongers' own terms would reveal an even higher degree of inter-minority diversity than that displayed in the Tables above. .

- That in the absence of a much fuller - and much more technically satisfactory disaggregation of ethnic affiliation than is currently on offer, comprehensive analyses of the multi-dimensional processes which have led different groups to follow widely varying socio-economic trajectories will remain beyond our grasp.

This clearly constitutes a very much wider agenda than the Home Affairs Select Committee and most of the other supporters of the introduction of an "Ethnic Group" question in the Census - initially envisaged. Judging by the majority of the analyses of the results of the 1991 exercise which have so far appeared, it is also way beyond the conceptual paradigms which still underpin the greater part of the current sociological and social policy debate about these issues. ${ }^{15}$

\footnotetext{
${ }^{15}$ For a further analysis along much the same lines, but this time focussing on the more demographic dimensions of the underlying issues, see my review article entitle "The construction of a conceptual vision: 'Ethnic Groups' and the 1991 Census in Ethnic and Racial Studies Vol20, pp. 182 - 194.
} 
Yet what are the chances of overturning established - and from an English perspective, all too convenient - conceptual paradigms? My own experience has made me ever more sceptical. Despite the urgency of the issues, progress is disappointingly slow. What seems quite clear is that in the absence of a radical improvement in both popular and social scientific understandings of the dialectics of ethnic pluralism - and hence of the way in which on-going processes of adaptation and closure within each of our society's many ethnic components are continuing to precipitate a diverse range of social and behavioural outcomes - we are unlikely to see much of a speed-up. Paradoxically enough sloganistic support for anti-racist policies - which themselves all too often offer little more than moralistic sympathy for the plight of the down-trodden and disadvantaged - is by no means incompatible with the maintenance of a conceptual framework which further supports (whether wittingly or unwittingly) well established structures of hegemonic ethnocentricity. By contrast taking alterity seriously, especially when that requires one to rethink one's own deeply entrenched ethnic presuppositions, is a far more challenging task. Current developments offer few indications that this is yet being seriously addressed.

\section{Biographical note}

Roger Ballard is a Social Anthropologist, and his current post is as Lecturer in Comparative Religion at the University of Manchester. 


\begin{tabular}{|l|rrr|rrr|rrr|}
\hline \multicolumn{4}{c}{ Aged 18 -29 } & \multicolumn{3}{c|}{ Aged 30 - 44 } & \multicolumn{3}{c|}{ Aged 45 - 59 } \\
\hline Men & Persons & Percent & Ratio & Persons & Percent & Ratio & Persons & Percent & Ratio \\
Large employers & 7 & 0.1 & 4.2 & 19 & 0.1 & 1.9 & 10 & 0.1 & 1.5 \\
Small employers & 515 & 3.9 & 2.6 & 1755 & 10.6 & 2.0 & 908 & 9.4 & 1.6 \\
Self-employed professionals & 83 & 0.6 & 1.7 & 524 & 3.2 & 1.5 & 418 & 4.3 & 1.9 \\
Self-employed non-professionals & 976 & 7.3 & 0.9 & 2481 & 15.0 & 1.3 & 1299 & 13.4 & 1.1 \\
Managers in large establishments & 337 & 2.5 & 0.7 & 831 & 5.0 & 0.5 & 404 & 4.2 & 0.4 \\
Managers in small establishments & 960 & 7.2 & 1.0 & 1651 & 10.0 & 0.8 & 680 & 7.0 & 0.6 \\
Employed professionals & 1092 & 8.2 & 1.4 & 1737 & 10.5 & 1.4 & 726 & 7.5 & 1.2 \\
Non-manual supervisiors & 99 & 0.7 & 1.0 & 108 & 0.7 & 0.6 & 75 & 0.8 & 0.9 \\
Manual supervisiors & 169 & 1.3 & 0.7 & 381 & 2.3 & 0.6 & 276 & 2.9 & 0.6 \\
Junior non-manual workers & 2673 & 20.0 & 1.3 & 1653 & 10.0 & 1.1 & 850 & 8.8 & 1.2 \\
Ancilliary Workers & 1257 & 9.4 & 1.0 & 1762 & 10.7 & 0.8 & 832 & 8.6 & 0.8 \\
Personal service workers & 1132 & 8.5 & 3.1 & 928 & 5.6 & 5.7 & 384 & 4.0 & 5.2 \\
Skilled manual workers & 2345 & 17.6 & 0.7 & 3430 & 20.7 & 0.9 & 2183 & 22.6 & 0.9 \\
Semi-skilled workers & 2004 & 15.0 & 1.0 & 2714 & 16.4 & 1.5 & 2189 & 22.6 & 1.6 \\
Unskilled workers & 548 & 4.1 & 0.8 & 636 & 3.8 & 1.2 & 748 & 7.7 & 1.8 \\
Farmers and agricultural workers & 14 & 0.1 & 0.0 & 15 & 0.1 & 0.0 & 11 & 0.1 & 0.0 \\
Members of the armed forces & 257 & 1.9 & 0.7 & 211 & 1.3 & 0.7 & 20 & 0.2 & 0.4 \\
\hline
\end{tabular}

Table 2: Distribution of economically active men by age group and socio-economic group, and ratios to their White counterparts.

Source 1991 Census Ethnic Group and Country of Birth Topic Report, Table 16

$* 1.00=$ same proportion as Whites in that socio-economic group; $0.5=$ half as many; $2.0=$ twice as many 


\begin{tabular}{|l|rrr|rrr|rrr|}
\hline \multicolumn{1}{|c}{ Aged 18 - 29 } & \multicolumn{1}{c|}{ Aged 30 - 44 } & \multicolumn{3}{c|}{ Aged 45 - 59 } \\
\hline Women & Persons & Percent & Ratio & Persons & Percent & Ratio & Persons & Percent & Ratio \\
Large employers & 3 & 0.0 & 9.5 & 7 & 0.0 & 3.6 & 2 & 0.0 & 1.2 \\
Small employers & 157 & 1.2 & 2.0 & 563 & 4.0 & 1.8 & 212 & 2.8 & 1.1 \\
Self-employed professionals & 40 & 0.3 & 2.7 & 118 & 0.8 & 1.7 & 69 & 0.9 & 4.1 \\
Self-employed non-professionals & 286 & 2.2 & 1.2 & 962 & 6.8 & 1.9 & 364 & 4.8 & 1.5 \\
Managers in large establishments & 414 & 3.2 & 0.9 & 412 & 2.9 & 0.7 & 100 & 1.3 & 0.5 \\
Managers in small establishments & 573 & 4.5 & 0.7 & 648 & 4.5 & 0.7 & 210 & 2.8 & 0.5 \\
Employed professionals & 525 & 4.1 & 1.7 & 466 & 3.3 & 1.8 & 132 & 1.8 & 2.1 \\
Non-manual supervisiors & 148 & 1.2 & 0.7 & 141 & 1.0 & 0.6 & 31 & 0.4 & 0.3 \\
Manual supervisiors & 57 & 0.4 & 0.9 & 98 & 0.7 & 0.8 & 65 & 0.9 & 0.8 \\
Junior non-manual workers & 6118 & 48.0 & 1.1 & 4296 & 30.2 & 0.8 & 1193 & 15.8 & 0.4 \\
Ancilliary Workers & 1631 & 12.8 & 0.8 & 3120 & 21.9 & 1.0 & 2002 & 26.6 & 1.5 \\
Personal service workers & 941 & 7.4 & 0.8 & 1059 & 7.4 & 0.9 & 702 & 9.3 & 1.0 \\
Skilled manual workers & 229 & 1.8 & 0.6 & 411 & 2.9 & 1.2 & 249 & 3.3 & 1.2 \\
Semi-skilled workers & 1381 & 10.8 & 1.2 & 2533 & 17.8 & 2.0 & 1722 & 22.9 & 2.1 \\
Unskilled workers & 316 & 2.5 & 0.8 & 693 & 4.9 & 0.7 & 931 & 12.4 & 1.1 \\
Farmers and agricultural workers & 17 & 0.1 & 0.2 & 14 & 0.1 & 0.1 & 15 & 0.2 & 0.2 \\
Members of the armed forces & 35 & 0.3 & 0.7 & 26 & 0.2 & 2.1 & 0 & 0.0 & 0.0 \\
\hline
\end{tabular}

Table 3: Distribution of economically active women by age group and socio-economic group, and ratios to their White counterparts.

Source 1991 Census Ethnic Group and Country of Birth Topic Report, Table 16

$* 1.00=$ same proportion as Whites in that socio-economic group; $0.5=$ half as many; $2.0=$ twice as many 


\begin{tabular}{|c|c|c|c|c|c|c|c|c|c|c|c|c|c|c|c|c|c|c|}
\hline \multirow[b]{2}{*}{ Men } & \multicolumn{6}{|c|}{ Aged 18 - 29} & \multicolumn{6}{|c|}{ Aged $30-44$} & \multicolumn{6}{|c|}{ Aged 45 - 59} \\
\hline & $\begin{array}{l}\text { Afro- } \\
\text { Caribs }\end{array}$ & Africans & Indians & $\begin{array}{l}\text { Paki- } \\
\text { stanis }\end{array}$ & $\begin{array}{c}\text { Bangla- } \\
\text { deshis }\end{array}$ & Chinese & $\begin{array}{l}\text { Afro- } \\
\text { Caribs }\end{array}$ & Africans & Indians & $\begin{array}{l}\text { Paki- } \\
\text { stanis }\end{array}$ & $\begin{array}{c}\text { Bangla- } \\
\text { deshis }\end{array}$ & Chinese & $\begin{array}{l}\text { Afro- } \\
\text { Caribs }\end{array}$ & Africans & Indians & $\begin{array}{l}\text { Paki- } \\
\text { stanis }\end{array}$ & $\begin{array}{c}\text { Bangla- } \\
\text { deshis }\end{array}$ & Chinese \\
\hline Large employers & 0.0 & 0.0 & 11.6 & 4.7 & 0.0 & 0.0 & 0.0 & 0.0 & 3.5 & 0.0 & 3.5 & 1.6 & 0.0 & 0.0 & 2.2 & 4.0 & 0.0 & 6.8 \\
\hline Small employers & 0.5 & 0.3 & 3.4 & 4.0 & 6.9 & 5.9 & 0.5 & 0.5 & 2.2 & 2.8 & 5.7 & 6.1 & 0.4 & 0.5 & 1.8 & 2.5 & 3.9 & 7.5 \\
\hline Self-employed professionals & 0.2 & 2.0 & 4.0 & 0.8 & 0.0 & 1.7 & 0.4 & 1.1 & 2.3 & 1.0 & 0.7 & 2.1 & 0.1 & 1.3 & 3.5 & 2.0 & 2.4 & 2.5 \\
\hline $\begin{array}{l}\text { Self-employed non- } \\
\text { professionals }\end{array}$ & 0.6 & 0.6 & 1.2 & 1.7 & 0.3 & 0.5 & 0.9 & 0.5 & 1.5 & 2.2 & 0.7 & 1.7 & 0.7 & 0.7 & 1.3 & 1.6 & 0.7 & 2.8 \\
\hline $\begin{array}{l}\text { Managers in large } \\
\text { establishments }\end{array}$ & 0.8 & 0.8 & 0.8 & 0.5 & 0.2 & 0.5 & 0.5 & 0.6 & 0.5 & 0.3 & 0.2 & 0.6 & 0.2 & 0.6 & 0.5 & 0.3 & 0.3 & 0.5 \\
\hline $\begin{array}{l}\text { Managers in small } \\
\text { establishments }\end{array}$ & 0.8 & 0.7 & 1.2 & 0.9 & 0.5 & 0.9 & 0.6 & 0.5 & 0.8 & 0.6 & 0.8 & 0.9 & 0.2 & 0.4 & 0.8 & 0.6 & 0.6 & 0.9 \\
\hline Employed professionals & 0.5 & 1.3 & 1.9 & 1.3 & 0.5 & 4.0 & 0.5 & 1.9 & 1.5 & 1.0 & 0.5 & 2.9 & 0.2 & 1.5 & 1.8 & 0.9 & 1.4 & 1.7 \\
\hline Non-manual supervisiors & 0.9 & 1.0 & 1.2 & 1.3 & 0.8 & 0.5 & 0.7 & 0.5 & 0.8 & 0.5 & 0.4 & 0.4 & 0.7 & 0.6 & 1.2 & 1.2 & 0.0 & 0.3 \\
\hline Manual supervisiors & 0.8 & 0.9 & 0.8 & 0.6 & 0.1 & 0.2 & 0.8 & 0.4 & 0.7 & 0.5 & 0.1 & 0.1 & 0.8 & 0.4 & 0.5 & 0.5 & 0.0 & 0.3 \\
\hline Junior non-manual workers & 1.3 & 1.5 & 1.5 & 1.3 & 0.4 & 0.8 & 1.0 & 1.5 & 1.2 & 1.1 & 0.6 & 0.8 & 0.4 & 1.9 & 1.6 & 1.2 & 1.0 & 1.1 \\
\hline Ancilliary Workers & 1.1 & 1.0 & 1.0 & 0.6 & 0.3 & 1.2 & 1.0 & 1.3 & 0.7 & 0.4 & 0.5 & 0.9 & 0.5 & 1.5 & 0.9 & 0.6 & 0.5 & 0.8 \\
\hline Personal service workers & 1.3 & 2.0 & 0.8 & 1.6 & 23.2 & 11.0 & 2.3 & 3.2 & 1.4 & 2.6 & 48.7 & 30.4 & 1.6 & 4.0 & 1.2 & 1.9 & 31.3 & 50.2 \\
\hline Skilled manual workers & 1.0 & 0.4 & 0.7 & 0.7 & 0.1 & 0.2 & 1.5 & 0.5 & 1.0 & 1.2 & 0.2 & 0.1 & 1.4 & 0.4 & 0.8 & 1.1 & 0.4 & 0.2 \\
\hline Semi-skilled workers & 1.1 & 1.0 & 1.1 & 1.6 & 0.5 & 0.2 & 1.4 & 1.2 & 1.8 & 2.2 & 1.1 & 0.2 & 2.2 & 1.5 & 1.5 & 1.9 & 1.5 & 0.3 \\
\hline Unskilled workers & 0.8 & 1.5 & 0.7 & 1.1 & 0.6 & 0.6 & 1.2 & 2.0 & 1.1 & 1.8 & 0.8 & 0.3 & 2.6 & 1.9 & 1.2 & 2.0 & 2.2 & 1.0 \\
\hline $\begin{array}{l}\text { Farmers and agricultural } \\
\text { workers }\end{array}$ & 0.1 & 0.0 & 0.0 & 0.0 & 0.0 & 0.0 & 0.0 & 0.1 & 0.0 & 0.0 & 0.0 & 0.0 & 0.0 & 0.1 & 0.0 & 0.0 & 0.0 & 0.0 \\
\hline Members of the armed forces & 0.5 & 1.5 & 0.1 & 0.0 & 0.0 & 0.2 & 0.7 & 0.6 & 0.1 & 0.0 & 0.1 & 0.2 & 0.4 & 1.4 & 0.1 & 0.0 & 0.0 & 0.9 \\
\hline
\end{tabular}

Table 4: Ratios of economically active non-white men to their white counterparts by age group, ethnic group and socio-economic group*.

Source 1991 Census Ethnic Group and Country of Birth Topic Report, Table 16

$* 1.00=$ same proportion as Whites in that socio-economic group; $0.5=$ half as many; $2.0=$ twice as many 


\begin{tabular}{|c|c|c|c|c|c|c|c|c|c|c|c|c|c|c|c|c|c|c|}
\hline \multirow[b]{2}{*}{ Women } & \multicolumn{6}{|c|}{ Aged 18 - 29} & \multicolumn{6}{|c|}{ Aged $30-44$} & \multicolumn{6}{|c|}{ Aged 45 - 59} \\
\hline & $\begin{array}{l}\text { Afro- } \\
\text { Caribs }\end{array}$ & Africans & Indians & $\begin{array}{l}\text { Paki- } \\
\text { stanis }\end{array}$ & $\begin{array}{l}\text { Bangla- } \\
\text { deshis }\end{array}$ & Chinese & $\begin{array}{l}\text { Afro- } \\
\text { Caribs }\end{array}$ & Africans & Indians & $\begin{array}{l}\text { Paki- } \\
\text { stanis }\end{array}$ & $\begin{array}{c}\text { Banglad } \\
\text { eshis }\end{array}$ & Chinese & $\begin{array}{l}\text { Afro- } \\
\text { Caribs }\end{array}$ & Africans & Indians & $\begin{array}{l}\text { Paki- } \\
\text { stanis }\end{array}$ & $\begin{array}{l}\text { Bangla- } \\
\text { deshis }\end{array}$ & Chinese \\
\hline Large employers & 0.0 & 0.0 & 19.4 & 0.0 & 0.0 & 0.0 & 0.0 & 0.0 & 8.0 & 0.0 & 0.0 & 0.0 & 0.0 & 0.0 & 2.1 & 0.0 & 0.0 & 0.0 \\
\hline Small employers & 0.3 & 0.2 & 2.7 & 4.7 & 3.3 & 6.7 & 0.2 & 0.4 & 2.2 & 4.8 & 1.1 & 6.6 & 0.1 & 0.3 & 1.7 & 4.6 & 0.0 & 5.4 \\
\hline Self-employed professionals & 0.7 & 1.8 & 4.4 & 2.6 & 0.0 & 2.3 & 0.5 & 1.2 & 2.4 & 3.1 & 1.8 & 2.6 & 0.0 & 0.9 & 7.7 & 26.3 & 28.9 & 3.3 \\
\hline $\begin{array}{l}\text { Self-employed non- } \\
\text { professionals }\end{array}$ & 0.3 & 0.7 & 1.6 & 3.3 & 1.9 & 2.4 & 0.4 & 0.8 & 2.7 & 4.3 & 1.0 & 4.5 & 0.3 & 0.7 & 2.9 & 5.4 & 2.0 & 3.5 \\
\hline $\begin{array}{l}\text { Managers in large } \\
\text { establishments }\end{array}$ & 1.2 & 1.1 & 0.8 & 0.6 & 0.1 & 0.6 & 1.1 & 0.8 & 0.5 & 0.4 & 0.7 & 0.7 & 0.4 & 0.7 & 0.3 & 0.0 & 0.7 & 0.4 \\
\hline $\begin{array}{l}\text { Managers in small } \\
\text { establishments }\end{array}$ & 0.7 & 0.7 & 0.7 & 0.6 & 0.3 & 0.9 & 0.6 & 0.6 & 0.6 & 0.8 & 0.4 & 1.2 & 0.3 & 0.4 & 0.7 & 0.8 & 0.8 & 1.4 \\
\hline Employed professionals & 0.6 & 1.8 & 2.3 & 1.3 & 0.4 & 6.6 & 0.6 & 2.0 & 1.9 & 1.8 & 3.8 & 3.7 & 0.2 & 1.2 & 4.0 & 3.0 & 15.6 & 3.0 \\
\hline Non-manual supervisiors & 0.7 & 0.5 & 0.9 & 0.6 & 0.0 & 0.2 & 0.8 & 0.4 & 0.6 & 0.4 & 0.0 & 0.3 & 0.4 & 0.2 & 0.2 & 0.4 & 0.0 & 0.2 \\
\hline Manual supervisiors & 0.7 & 1.5 & 1.0 & 1.6 & 0.0 & 0.5 & 0.9 & 0.5 & 1.1 & 0.5 & 1.0 & 0.4 & 1.1 & 0.3 & 0.6 & 0.9 & 0.0 & 0.2 \\
\hline Junior non-manual workers & 1.2 & 0.9 & 1.2 & 1.0 & 0.9 & 0.7 & 0.9 & 0.7 & 0.9 & 0.7 & 0.5 & 0.7 & 0.3 & 0.4 & 0.6 & 0.5 & 0.6 & 0.6 \\
\hline Ancilliary Workers & 0.9 & 1.0 & 0.7 & 0.7 & 0.7 & 0.9 & 1.4 & 1.2 & 0.6 & 0.9 & 1.0 & 1.4 & 2.0 & 2.1 & 0.8 & 1.2 & 1.9 & 1.3 \\
\hline Personal service workers & 0.9 & 1.2 & 0.3 & 0.5 & 1.8 & 2.4 & 0.8 & 1.4 & 0.5 & 0.9 & 1.8 & 1.9 & 1.1 & 1.3 & 0.4 & 0.9 & 0.7 & 2.6 \\
\hline Skilled manual workers & 0.5 & 0.3 & 0.6 & 1.1 & 1.3 & 0.0 & 0.8 & 0.8 & 1.9 & 1.5 & 1.0 & 0.2 & 1.0 & 0.6 & 2.0 & 1.2 & 1.5 & 0.4 \\
\hline Unskilled workers & 0.6 & 2.9 & 0.5 & 0.4 & 0.3 & 1.1 & 0.6 & 1.8 & 0.5 & 0.4 & 0.4 & 0.6 & 1.4 & 1.3 & 0.6 & 0.5 & 0.7 & 1.1 \\
\hline $\begin{array}{l}\text { Farmers and agricultural } \\
\text { workers }\end{array}$ & 0.2 & 0.0 & 0.2 & 0.6 & 0.8 & 0.0 & 0.1 & 0.2 & 0.2 & 0.5 & 0.0 & 0.0 & 0.0 & 0.2 & 0.3 & 1.0 & 0.0 & 0.8 \\
\hline Members of the armed forces & 0.3 & 1.4 & 0.1 & 0.0 & 0.0 & 0.0 & 0.3 & 3.9 & 0.0 & 0.0 & 0.0 & 0.0 & 0.0 & 0.0 & 0.0 & 0.0 & 0.0 & 0.0 \\
\hline
\end{tabular}

Table 5: Ratios of economically active non-white women to their white counterparts by age group, ethnic group and socio-economic group*.

Source 1991 Census Ethnic Group and Country of Birth Topic Report, Table 16

$* 1.00=$ same proportion as Whites in that socio-economic group; $0.5=$ half as many; $2.0=$ twice as many 